\title{
Assessing the Main Priorities Area and Opportunities for Banks Financing in Leather Industry in Ethiopia
}

\author{
Moroda kenea Duresa \\ Senior Research and development Officer \\ Awash Bank, Addis Abeba Ethiopia
}

\begin{abstract}
This assessment is to identify the main opportunities of Ethiopian Banks for financing in leather sector. This can be done by analyzing data and drawn conclusions. The assessment also tries to identify comparative advantage of financing on leather sectors on banking performance. Also identified specific area of sub sectors to play significant roles in generating income from especially, exporting of the raw hides, skins, in leather sector. Also found from the assessment that Ethiopia have potential economy in the sectors because of the availability of such raw material, and high market supply of demand of leather from excess resource. Raw Hide and skin, and leather and finished leather sector has huge potential to achieve foreign exchange for Ethiopia, it is identified as one of the potential sectors that could play a crucial role in achieving long run the foreign currency earning of the country, expanding employment opportunities and attracting foreign direct investment (FDI) due to abundant labor and excess raw material. Then found, gain from the contribution of this sector to the country's economy, highly significant and demanded in many international markets. The main export destination of Ethiopian leather and leather product are: China, Europe union's countries (Italy, Germany, UK.), Japan, Hong Kong, United States of America, the main source of foreign exchange earner in each year.
\end{abstract}

Keywords: Leather, Leather product, Benefit, export

DOI: $10.7176 / \mathrm{RJFA} / 13-1-01$

Publication date: January $31^{\text {st }} 2022$

\section{INTRODUCTION}

\subsection{Background of the Study}

Awash bank is one of the private commercial banks in Ethiopia that aggressively works on expanding its business throughout the country. The bank work on expanding its customer base and identifying the target sectors and business which can enhance the bank's business activities. To confirm with government prioritized sector, Awash bank also undertake the study to distinguish the sectors that have contribution for country's economy and for Awash bank, if the bank provides services for the sectors' improvement. Thus, this study is conducted to identify the viability of leather and leather product by assessing how the bank can interfere in the marketing of leather product and its production process to retain their stakeholders to provide banking services.

Leather industry is a very old manufacturing sector producing a wide range of goods such as leather footwear, leather bags, leather garments, and so on. It is one from five highest exporting product, dominant product in Ethiopia. The raw material used in leather industry is derived from the of food industry, specifically from meat processing. This product is converted into desirable and useful leather products. They are produced from renewable and readily available resource (LII, 2011).

Leather and its products are one of the most traded products globally. According World Trade Organization (WTO,2015), leather industry trade is presently exceeding US\$80 billion in a year and grown as increase in population and urbanization of the countries. It is being among the most dominantly produced, traded and commonly used commodities in the world. Different studies reveal that the total value of annual trade of the leather is estimated more than many times than coffee and rice in the world. Studies also suggest that formal international trade in leather and leather products is estimated at over year to year, who suggest that there is high demand of leather and leather product. This, includes demand for leather raw materials like hides and other leather products exceeds than its supply, leads to raising prices and making the leather industry one of the most necessary business sectors in economic circulation.

Leather used as supporting economic growth and development, more specifically, as necessity for clothing \& shelter for human beings in different countries, as decoration and luxury rather than a necessity in developed country, like a home with leather furniture, a car with leather seats, and a celebrity worn leather jacket indicate different status and fashion. It also, plays a significant role in the world economy as widely commercialized commodities in the world and the industry accounting for trade flows worth of US \$ \$233 billion in 2016 spread over 200 exporting countries (as global statistics, 2018). The global international trade suggests that footwear has a share of 57.7 percent, followed by leather products with 31.1 percent and raw and finished leather 11.2 percent in 2016. The major 25 importers have a share of $88.7 \%, 85.6 \%$ and $80.9 \%$ for raw hides and skins and leather, leather products and footwear respectively.

The leather sector is identified as one of the potential sectors that could play a crucial role in achieving long 
run development objectives and transforming the country's development status to a higher level by increasing the foreign currency earning of developing the country, like Ethiopia, by expanding employment opportunities and attracting foreign direct investment (FDI). This is due to domestic livestock population in Ethiopia is estimated to constitute at 27 million cattle, 24 million sheep and 18 million goats, meaning that raw hides and skins are readily available from the local market. This makes Ethiopia is the first in Africa and the tenth in the world for its abundance of livestock in currently, by suggesting Ethiopia has vast potential of leather avail it for the export market to close foreign exchange gap, earn foreign currency gain and vital role for country's economic growth implying the industry has enormous potential (CSA,2015). It is not only about the sheer number of cattle, sheep and goats, but also that Ethiopian goat and sheep skins are preferable to other countries' products in terms of quality.

\subsection{STATEMENT OF THE PROBLEM}

Leather and leather products sector in Ethiopia are one of the basic sources of economies in to solve the foreign exchange gap via its export. In other cases, Ethiopian leather industry experienced very oldest sector, in the production of leather and leather products, the industry lacks of modern technology and use most traditional way of production not competitive in the local and international markets.

In addition, although the industry lacks of financing for competing in the international market, the sector has comparative advantage of producing leather and leather products. Relative to other sectors, it has lower cost and one of the priority sectors to collect foreign currency from export, showing that the country has abundant raw material for leather and leather products. Currently, the industry has showing trajectory on export of leather and leather product growing over the years. But, no one knows the opportunity and advantage in the sector. This causes the banks should to consider at more closely in order to invest on new untouched product and got comparative advantage.

\subsection{General Objective of the study}

The general objective of the study is to assess the main priorities area and opportunities of Banks for financing of leather industry; specifically, it aims to:

- Identify the availability of raw material for leather product (livestock);

- Examine supply-demand analysis of leather product and its export performance;

- To identify the destination markets of Ethiopia's leather and leather products export;

- To show and explain market channel and value chain of leather product in which bank can get comparative advantage in investing the leather industry,

- Suggest financial challenges and opportunities of leather and leather product in Ethiopia

\subsection{Research Methods and Analysis}

For this assessment used, secondary data are collected from various sources including online sources and Ministry of Trade and industry, Central Statistics agency, Leather and leather industry association, International trade corporation. For data analysis, descriptive statistics like simple statistical methods such as percentages, averages and growth rate are utilized and presented in the form of graphs and tabulations.

\section{Overview of Leather and Leather Products \\ 2.1 Leather Product as Sector}

The leather sector can be classified in the following core sub-sectors: raw hides and skins production, collection and commercialization; tanning and leather finishing; leather products manufacture, manufacturing of footwear; manufacturing of other leather output products. In order to produce finished product of leather, there is a number of auxiliary and capital goods provide inputs to the leather sector semifinished and finished leather chemicals, footwear auxiliaries, leather goods auxiliaries of production equipment (World Bank Group,2015).

Leather products' industry may be footwear, garment and other leather goods. It is related to skin, hides and the leather products shoes, garment and leather goods are important export earner for many developing countries and characterized as the main contributor to the country's export and employer of labor-intensive industry provides employment to the most vulnerable groups of the society in urban and rural where other job opportunities are very scarce. Most of the leather products and footwear industry is dominated by small and medium scale industries. The leather product industry is characterized by skill and knowledge, whereas there is a lack of skilled labor to use modern technology for producing quality product for applying technology and productive technology.

Ethiopian leather sector is composed of raw hides and skins traders, leather tanneries, which source their supply mostly from the local market, and footwear producers, who use both local and international markets for raw material supply. The most important source of raw material for leather tanneries are hides and skins that are procured from skin collectors and traders. Ethiopia's leather and leather product sector produces a range of 
products from semi processed leather in various forms to processed leathers including shoe uppers, leather garments, stitched upholstery, backpacks, purses, industrial gloves and finished leather (CSA,2015).

\subsection{Overviews of Leather Production and Export at Global Trends}

Leather has many economic benefits, and it is being a highly specialized industry sector, has multiplier effect on the manufacturing industry deferent product improvement, marketing, business networks development and enhancement of export-oriented support services and absorbing foreign currency. Production and supply of leather have gradually moved from industrialized to developing countries and developing countries' economies, which are now becoming crucial role in the trade. In fact, counties of emerging economies can now be trying to surge and accomplish supply chain as output on their own and are fast becoming the most important suppliers of valueadded finished products. The supply chain is global and a great deal of trade currently performed is the least developing country to the least developing countries and developing country to developed country (ITC, 2019). On other hand, the least developed countries like of African countries have comparative advantage their large livestock, have a remarkable growth potential of leather and leather product, recently also not untapped. This is the most probable due to weaknesses in technical how to operate, access to market information, visibility, quality management, marketing, investments and international industrial alliances.

Some studies suggest that, hides and skins have been one of the country's top foreign currency earners, as to coffee, chat, and oil seed export, the highest foreign currency earner. According to CSA, 2011, Ethiopia earned 139.28 million USD from the export of finished leather, shoes, garments, and gloves to foreign countries. In addition to this, export of high value products such as, shoe, leather glove and leather clothing and accessories contributed 17.16 percent of the total export, a 104. 11 percent increase in 2013 compared to the same period in 2012 in the previous Ethiopian fiscal year. In the first eight months of the 2012 fiscal year, Ethiopia has earned USD 5.8 million from export of shoes. In the 20113 current budget years, the performance of the industry has doubled by exceeding the previous year's performance for the same period by USD 5.7 million. Additionally, individuals employed by the sub sector which is yearly reached more than 20,000 and earning about USD 15-16 million from the sub sector products, with significant export performance.

In line with the development priorities of the least developing countries and the objective of increasing trade through improved visibility of marginalized industries, and got earning the foreign currency to provide to put leather sector top priority. Information and communication technologies can make countries an impressive amount of information available, especially countries should have worked recognized in the international market. The entrepreneurs in developing countries, and increase the visibility of their leather industry to allow them to enter the global supply chain network, and so improve and expand their trade.

\subsection{Overview of the Development of the Leather Sector in Ethiopia}

According (USAID 2013), report the leather industry in Ethiopia can be segmented into three sub sectors: the production of finished leather from raw hides and skins tanneries, manufacturing and the production of leather footwear, and the production of other leather goods such as garments, bags, gloves, belts and accessories. The two leather sectors, tanneries and manufacturing, are processing domestically produced and imported finished leather. They also have to import most other inputs, including chemicals, but also simple packaging materials like wrapping papers and shoe boxes. Additionally, the recovery and collection of skins and hides, at the upper end of the value chain, is a critical element for the overall development of the leather sector. At present, the domestic value chain is not well integrated, cooperated and most participants in the leather supply chain operate independently instead of interdependently, this harm the industry development exchange of technology know how.

In the meantime, currently, Ethiopia has seen a significant increase in foreign investment in leather processing and manufacturing especially denominated from China. By making flexible policy measures and tax relaxation on new foreign investment in tanneries become motivated in investing, due to lack of local tanneries' ability to use technology to produce and supply to international market. For example, according (Brautigam, 2011), FDI from China to Ethiopia increased from US\$0.43 million in 2004 to US\$58.53 million in 2010 in the leather sector. However, many studies suggest inflows of FDI in the leather industry of local tanneries and manufacturer; rather than being sources of technology transfer, foreign tanneries overall are regarded as undesirable and unfair competition with those high potential investors on raw material collection. On other hands, larger tanneries equipped with machines and the required facilities buy semi processed products from other tanneries and this leads to improvements in the leather value chain. The leather industries buy raw materials from the tanneries and produce various types of finished leather products; both for domestic use and export purposes finished product of leather (USAID, 2013).

\subsection{Supply and Demand structure of the leather sector}

In the tanning and manufacturing industry, there is growing power of suppliers, both globally and locally. Suppliers of raw hides and skins are demanding higher prices where do customers need low prices. In some countries, 
suppliers had to process the raw material to the semifinished, being sold immediately to tanners for processing. On the other hand, manufacturers shift to finished leather production than customers, and buyers may negotiate for prices.

Ethiopia is one of the best suppliers in the world for supplying in the leather and leather product because Ethiopia is endowed with abundant raw materials required for the industry to grow. Ethiopia has a huge population of livestock, which accounts for $21 \%$ of the world's cattle and $11 \%$ of the world's goat and sheep population. But, apart from the easy availability of raw materials, investors are able to trying to enjoy by investing an easy and abundant supply of skilled manpower, with world-class technology, competent and favorable environmental standards. Ethiopia has huge global market opportunities as well to COMESA, AGOA, Europe, EBA, China, India, Japan, etc. The global leather market is worth about USD 160 billion, with shoe alone claiming 200 billion USD (FAO, 2015).

According, (ELIA, 2019), report about 80 percent of all hides and skins entering the formal market are from rural areas where they are collected by private traders. The remaining 20 percent are derived from slaughtering facilities in major towns and cities. The Ethiopian leather sector is composed of raw hides and skins traders; leather tanneries, which source their supply mostly from the local market; and footwear producers, who use both local and international markets for raw material suppliers. The most important source of raw material for leather tanneries are hides and skins that are procured from skin collectors and traders. Manufacturer produce Value added finished leather products are produced under private Ethiopian labels, for shoes and other accessories. Whereas other factories sell directly to overseas importers, wholesalers, or to direct buyers, who facilitate the production and export of footwear and other finished leather products under the private labels of department stores, boutiques, shoe retail chains and order houses, as well as internationally well-known brands under contract. According to Leather Industry Development Institute (LIDI ,2019), In Ethiopia there are 27 tanneries and above sized 26 leather products manufacturing companies and 448 small and micro manufacturers in the country in which most of those tanneries are located in Addis Ababa and adjacent cities such as Mojo, Holeta, Sebeta, Bishoftu and others our regional cities, like Bahirdar, Hawasa, Adama, Kombolcha. Thus, the number of manufacturers/suppliers is large enough, and they produce differentiated or similar products, where the main differences relate to the quality of the products they produce.

\section{DATA ANALYSIS AND INTERPRETATIONS}

\subsection{Ethiopian Leather source}

Africa has constituted about 15 percent of the world's cattle population, from which Ethiopia has got numerical advantage of cattle, sheep and goats which make the country one of the most livestock populous in the world, $1^{\text {st }}$ in Africa, Ethiopia constitute about 11.8 percent of African livestock share. The Ethiopian livestock increases roughly about 25 to 50 percent yearly, growing significantly. As presented in table 3.1 below, shows that the increasing of share of livestock resources, used as encouraging opportunities for the leather and leather products sector. On other hands, this livestock population is very significant potential and possible strength for the country to source domestically produced hides and skins as an input for the domestic manufacturers in the leather sector. Access to domestic inputs would play a vital role in boosting the export performance of the country, as rising export then support the country's economic growth.

Table 3.1 Ethiopian share of livestock from 2005 to 2015 from Africa

\begin{tabular}{|l|c|c|c|c|c|c|c|c|c|c|}
\hline Year & 2005 & 2006 & 2007 & 2008 & 2010 & 2011 & 2012 & 2013 & 2014 & 2015 \\
\hline Cattle Share & 16.77 & 17.52 & 18.7 & 18.36 & 18.48 & 18.85 & 18.73 & 18.54 & 18.84 & 19.30 \\
\hline Sheep Share & 8.25 & 9.24 & 9.68 & 9.57 & 8.88 & 8.3 & 8.57 & 8.77 & 8.68 & 8.62 \\
\hline Goat Share & 5.97 & 6.73 & 7.19 & 6.95 & 7.02 & 6.8 & 7.09 & 7.23 & 7.15 & 7.39 \\
\hline
\end{tabular}

\section{Source: Personal computation FAO,2015}

\subsection{Analyzing Ethiopia's leather sector export performance \\ 3.2.1. Raw hides and skins and leather}

The leather industry very highly demanded sector of export. Figure 3.1 below shows in during 2011 about the $80 \%$ of export of Ethiopia constitute by leather product. Additionally, data suggest that from the whole export of Ethiopia, Ethiopian leather sub sector constitute about averagely 5.6 percent from the 2001 to 2016. 
Figure.3.1 Share of Leather industry from whole national trade

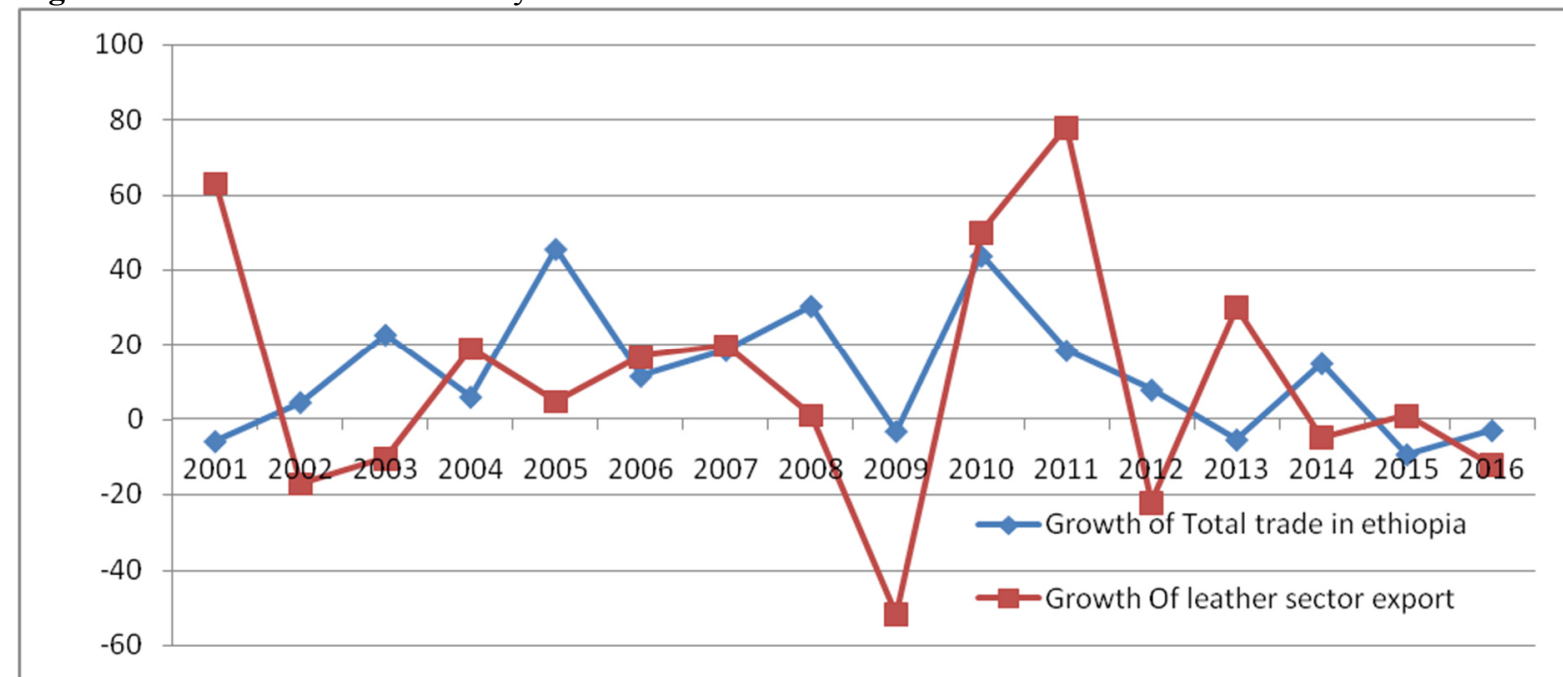

Own Graph from ERCA,2015 data

The export performance of the raw hides and skins and leather for the last ten years starting from 2001 to 2017 shows that there are huge variations across the country. Figure 3.2 below demonstrates that when Ethiopia introduced the highest export for raw hides and skins in 2017 which generate US\$41,866,000, from China, implies that china become the main and first distinction during the period. It also suggests that Ethiopia raw hides and skins are exported the first to earn foreign currency for the country. The next important market destinations of Ethiopia's raw hides and skins and leather Italy, during 2001, 2007 and 2011 which is earned about US\$33,599,000, US $\$ 30,808,000$, US\$39,439,000, respectively. This shows that the two i.e. China and Italy are the first two countries world's top importers of Ethiopian. Additionally, Hong Kong is the third distinction of raw hides and skins and leather during selected period 2013 which is reached about US\$35,029,000. Generally, China, Italy, Hong Kong and United Kingdom are the first fourth importer of Ethiopia raw hides and skins and leather. This suggests that Banks have to work collaborate with raw hides and skins and leather sector value chain so that the bank can gain high value of foreign currency from main importer of this product. 
Figure 3.2: Ethiopia raw hides and skins and leather export value earned from 2001 to 2017

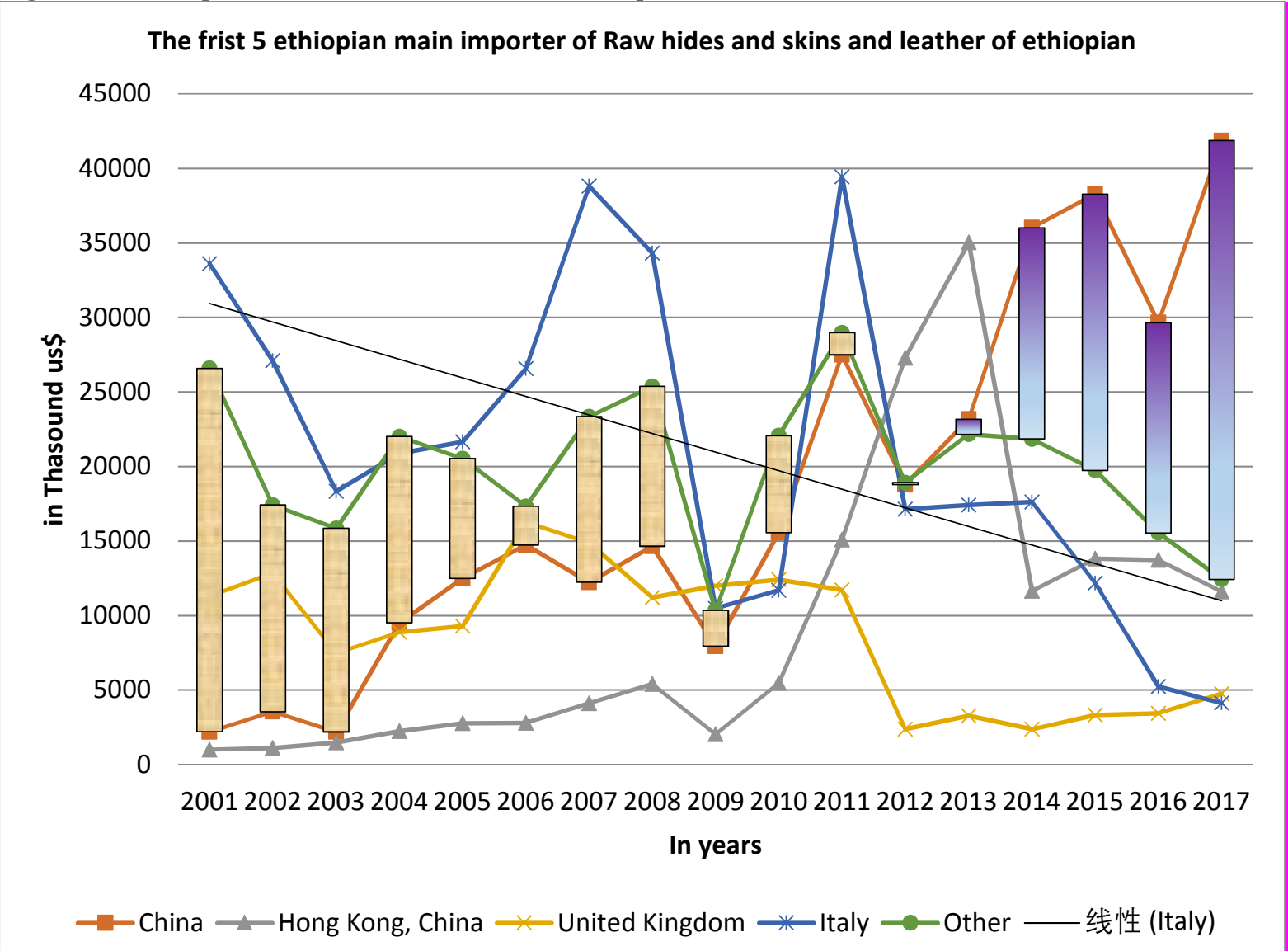

Figure 3.2 owners' graph from UN COMTRADE and ITC statistics.

On the other hands, when we consider the share of Ethiopia raw hides and skins and leather export value earned from 2001 to 2017, China shows the lions share which was the largest market share for Ethiopia's raw hides and skins products in from the lowest $2 \%$ in 2001 to grown to 56 percent in 2017 . The next higher shareholder of Ethiopia's raw hides and skins products export was Italy which was declined significantly from the highest 45 percent in 2001 to 5.5 percent in 2017, this probably due to high export tax on Ethiopian product. This implies focused on exporting its raw hides and skins by shifting from high export tax to lower export tax Italy to China. 
Figure 3.3: Ethiopia Share raw hides and skins value earned from 2001 to 2017

THE SHARE FRIST 5 IMPORTER OF ETHIOPIAN RAW HIDES AND SKIN,LEATHER

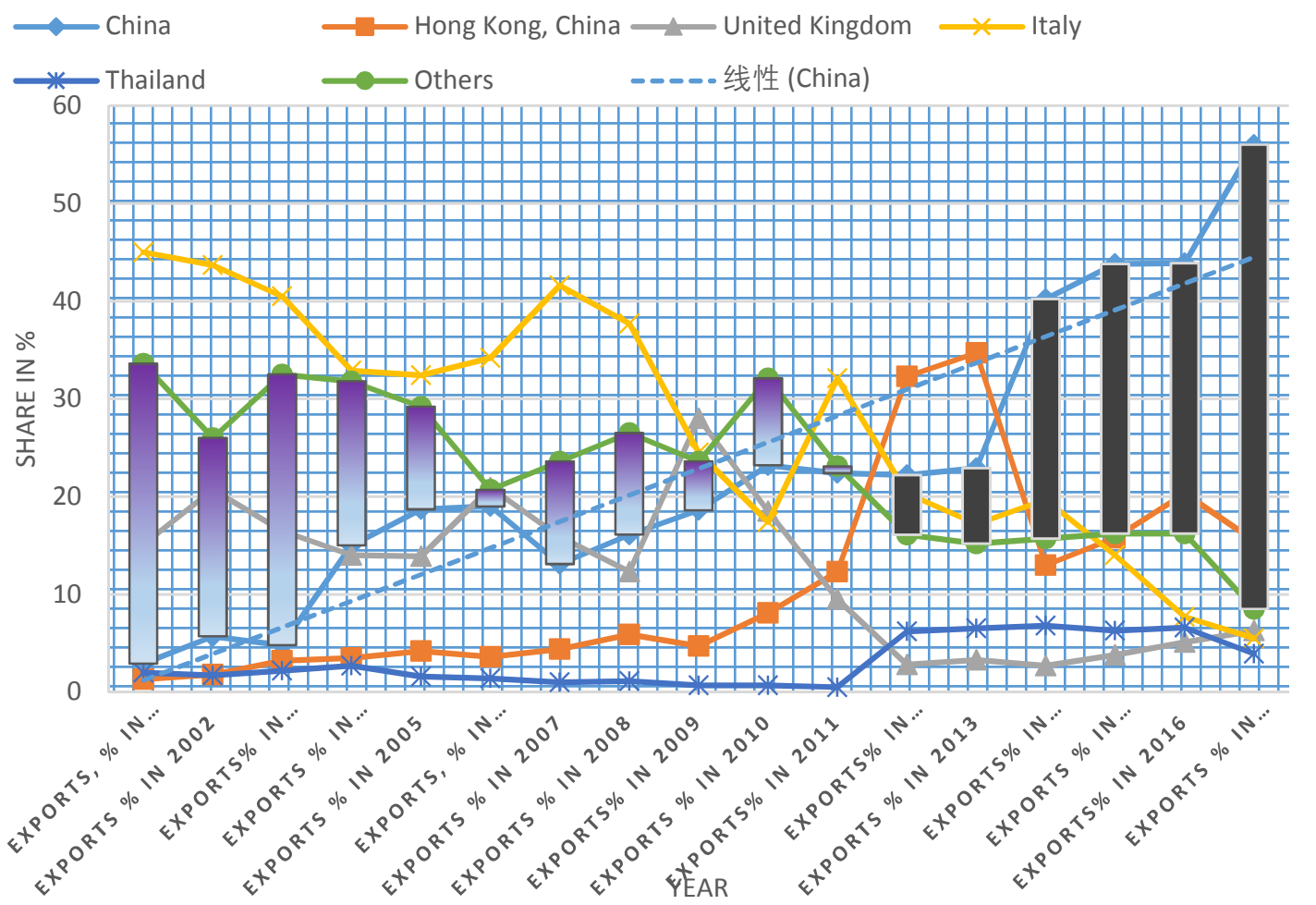

Fig 3.3 owner graphing from UN COMTRADE

From all product of raw skin, hides and leather tanned or crust skins of sheep or lambs, without wool on, whether split (excluding further prepared), is considered as the best and the engine product of for the entire leather industry which shown below in coded by " 4105 " below on figure 3.3 below. From the figure we can tanned or crust skins of sheep or lambs, without wool on, become accounted for the highest share in exports of raw leather and leather during 2011 which it became $\$ 64695000$ and become declined to 0 during 2012. The next best product which is exported during selected period is Semi Leather tanning or crusting leather and patent laminated leather which is coed by ' 4112 ' 'below which is become higher exported product during 2013 which was recorded about $\$ 64195,000$ then Footwear ' 6403 ', Leather further prepared after tanning or crusting "incl. parchment-dressed leather", of goats" 4113 " are the first $3^{\text {rd }}$ and $4^{\text {th }}$ highly exporter product of raw skin and hide and leather product of Ethiopia from the 2001 to 2019(Appendix.IV). Additionally, the data suggest that the raw skin and hides and leather product of Ethiopia are become more and more demanded to customer of in international market in recent time.

Generally, the export of product of Skin, Hides and leather product shows alarming growth from $\$ 65012,000$ to grown to $\$ 120321,000$ from the period from 2005 to 2019 , during this period the whole export of this raw skin and hides and leather reached about $\$ 2,932,872,000$ in 2019 . This figure implies that $A B$ has numerous advantages in financing in leather and leather product sector 
Figure 3.4 The Ethiopia's leather and leather product exported at international market in types (2001 -2019)

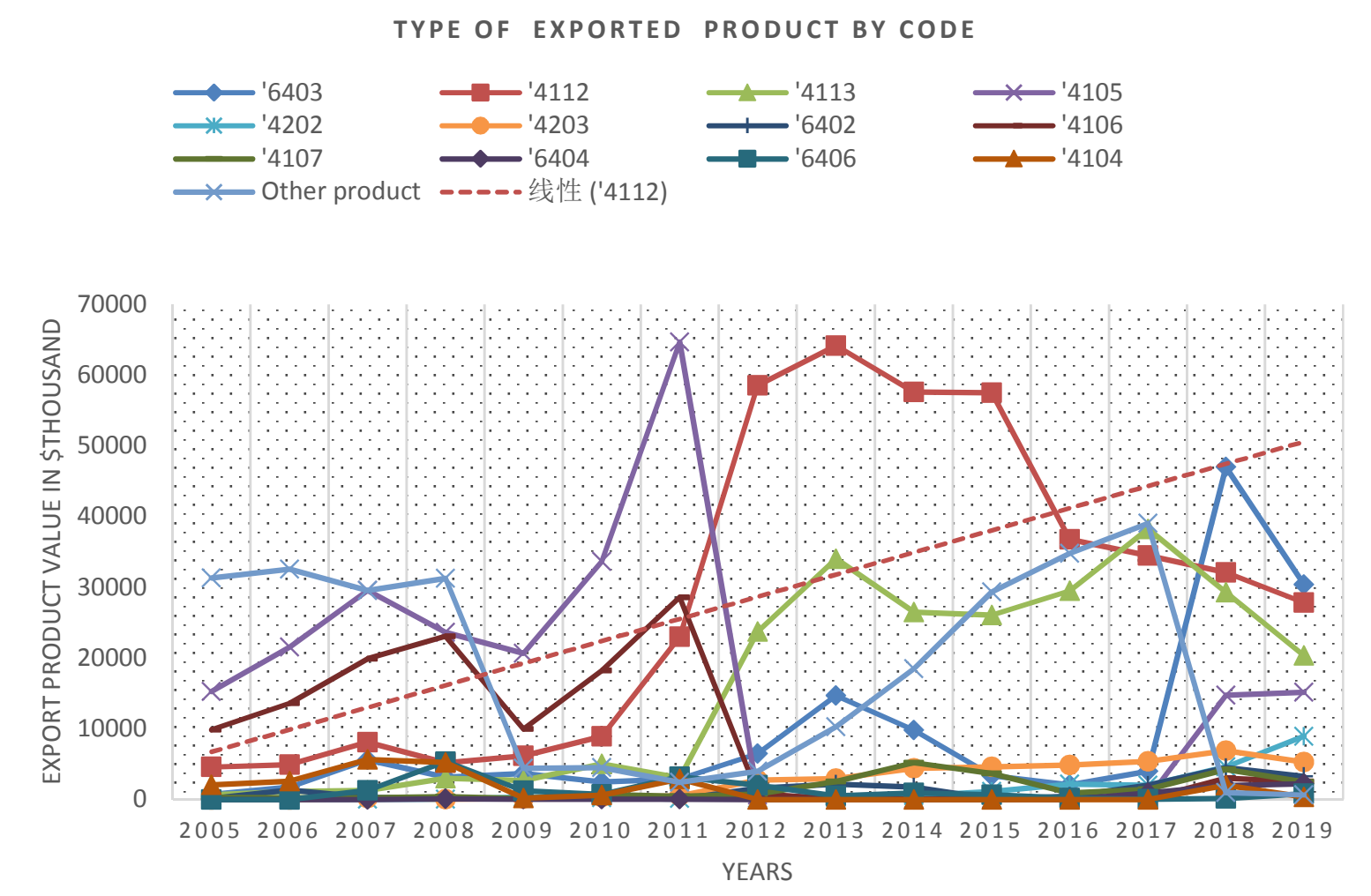

Fig 3.4 owner graphing from UN COMTRADE

3.3 Leather Finished product (Articles of leather; saddlery and harness; travel goods, handbags and similar containers; articles)

The major markets in distinction for Ethiopian's Leather Finished product (Articles of leather; saddlery and harness; travel goods, handbags and similar containers; articles) 2001- 2017 were United States of America (USA) with the greatest share of $70 \%$, with significant rising rate from $\$ 463,000$ in 2012 to become grown to $\$ 5,625,000$ in 2017(Appendix data). The next finished leather product of Ethiopian importers is Germany (11.8\%), Japan (3.5\%), United Kingdom (3\%), and China (2.3\%). This implies that future growth of the finished leather exporting Ethiopia will continue to be market driven, and oriented towards higher foreign exchange the Europe countries and the United States of America markets. The figures suggest that AB should have ways to work with export finished leather product (articles of leather; saddlery and harness; travel goods, handbags and similar containers; articles) to get foreign gain advantage in the sector(Fig.3.5) 


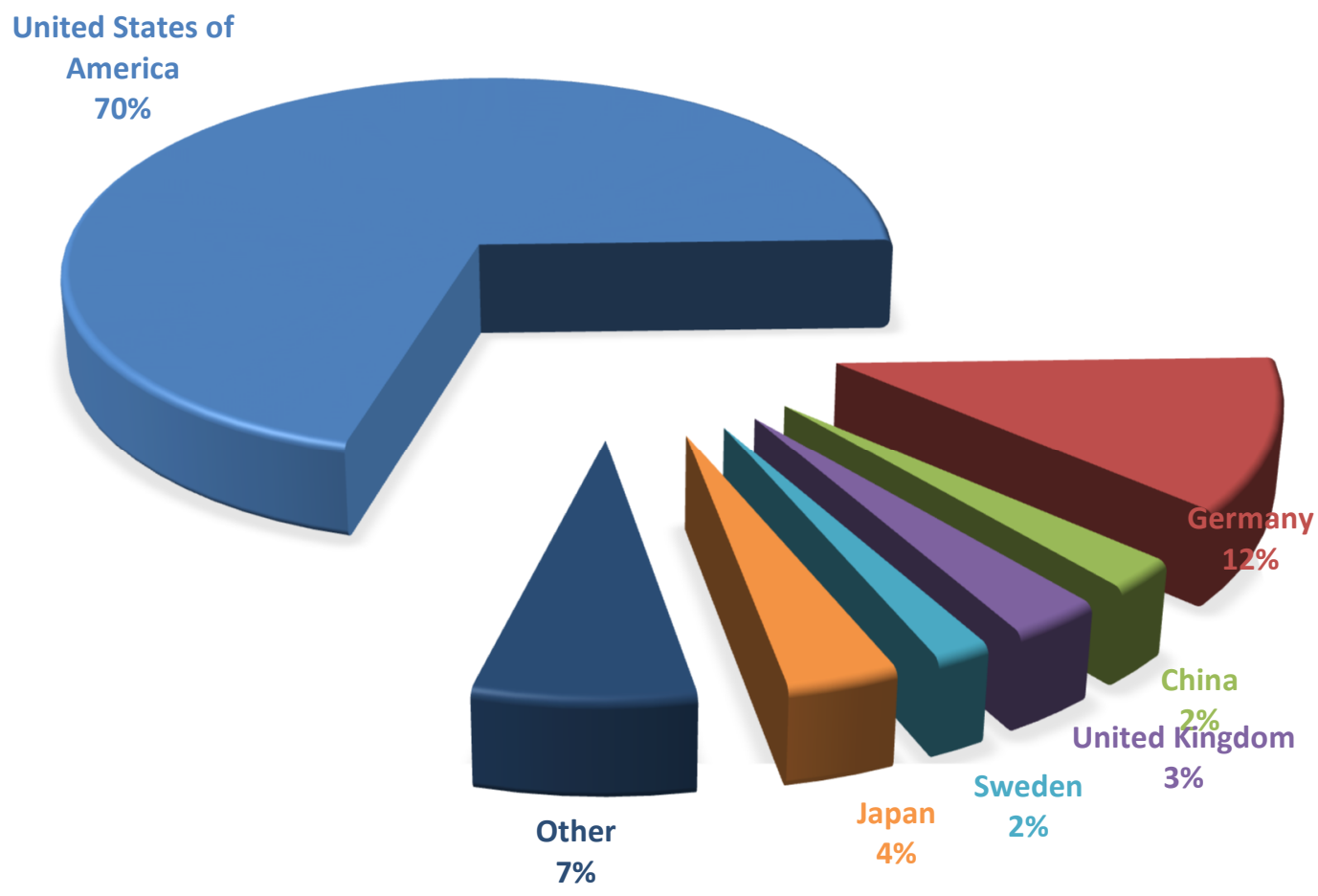

\section{Source; Personal graph from ITC statistics data 2020}

The leather and leather products sector is the fifth-largest export sector of Ethiopia, which is considered as highest priority sector, and it's increasingvalue addition. This implies that the sector become export of raw and semifinished product share become raised from 91.7 in 2007 percent to decline in 2016 to about 60 percent, whereas finished leather product become raised from about 10 percent to about 40 percent in 2016 . Finished leather represents the largest share of Ethiopia's output and export, and it accounted for around 5.6 percent of total leatherrelated exports in 2016. In parallel, finished leather exports rose from \$25.3 Million to \$67.6 Million during the same period, the main destinations being China, Hong Kong, Italy, Thailand India and United Kingdom which constitute $88.8 \%$ share ((Appendix.III) ERCA, data, 2017).

\subsection{Ethiopian leather Value chains}

The leather supply chain covers the recovery of raw hides and skins, their preservation until tanning, progressive tanning operations with several degrees of leather finishing, use of the leather for the manufacture of finished leather products, such as footwear and leather goods. Exports of leather takes place at each step of the supply chain and the driving factor is quality, as this affects the progression of the process and the export competitiveness of the raw, intermediary or finished products. Quality of leather is the result of the application of the correct techniques and work organization, and lack of market and absorbing buyer's specifications to ensure marketing success.

The Ethiopian leather value chain is inclusive of livestock farmers, livestock traders, butcheries, slaughter facilities owners, hides and skins traders and exporters, tanners, artisanal footwear and leather footwear manufacturers, and goods manufacturers. According (CSA, 2012) survey suggests that on livestock resources, Ethiopia has 53.4 million cattle, 25.5 million sheep and 22.7 million goats; this implies that lays the country as one of the richly endowed countries in livestock resources. It is estimated that the country can collect, 3.7 million cattle hides, 8.4 million sheep skin and 7.7 million goat skin. The sheep skins are well known for their quality. The goat skins in particular are known for their quality and international acceptance. Both goat and sheep skins are preferred for leather garments and gloves manufacturing, in addition to being used for shoe upper. The resource endowment of the country illustrates the considerable potential of the country in the leather industry.

Ethiopian which is composed of four sub-industries tanning, footwear, glove, and leather garment and goods shows moderately earning. According to the sector figures, the export for the sector in 2011/12, 2012/13, 2013/14, and $2014 / 15$ is USD $112,123,132$, and 116, respectively. Contribution to the economy is third place after coffee 
and oil seeds with a GDP contribution of 9 billion birr. Ethiopia’s leather exports currently standing at \$123 million, by the end of 2019, the government of Ethiopia trying to rise the leather industry's annually exports to $\$ 800$ million (ELL report, 2019). By increasing the country through value addition, the industry, creating more jobs and further boosting exports. The sector has now experiencing more than triple growth and employee more individual. The sector also became strategic for the Ethiopian economy pillars which financial industry also should have focused on the sector. Additionally, leather has been at the core of Ethiopia's economy for many centuries. As livestock are predominantly owned by smallholder farmers and pastoralists, considerable livelihood gains are expected to grow to rural populations' economy going forward.

\section{Fig:3.5 Overview of Ethiopian Leather Value Chains}

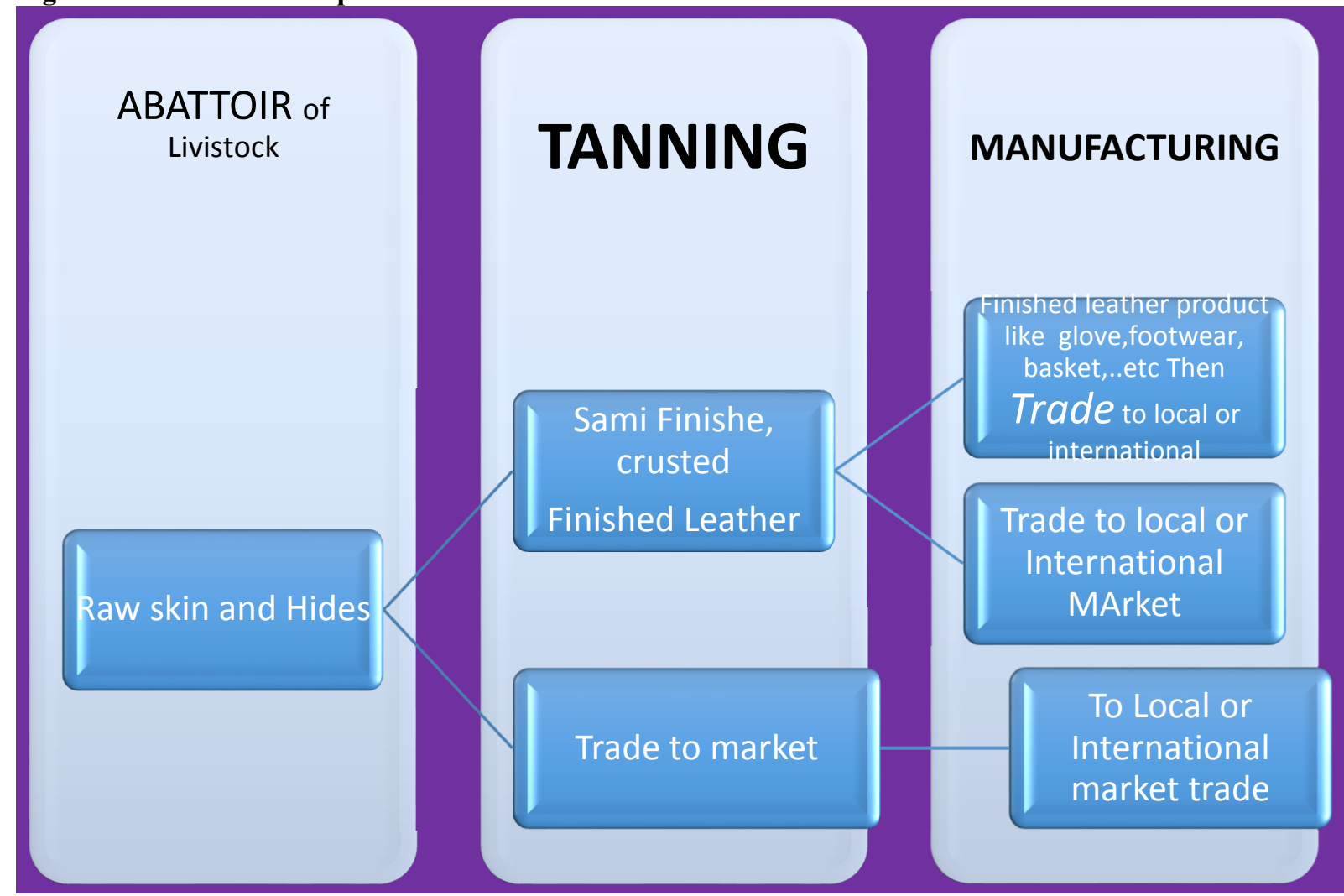

Source: Author developed graph

3.4.1 Key stakeholder's/Key players in the leather industry value chains

1. Abettors/Slaughter/Collection

Rawhide/skins must be conserved after the animal has been slaughtered (sometimes at an Abattoir) and then raw skin and hide is collected.

2. Tanning: After raw hide and skin is collected from abattoir, chemicals are absorbed by the hides and skins to turn them into wet blue. By tanning, the skin/hide is irreversibly chemically preserved and converted from wet blue into crust., using different chemicals and equipment, crust can be dyed, treated with coloring, waterproofing, and more. Semi - Finished leather is then ready to export or to be used in factories for the manufacturing of leather products.

\section{3. leather products manufacturing}

When semifinished left from the tanneries, it is absorbed, used in manufacturing industries then so that finally output of leather article, glove, bags, etc. become ready for export of locally or international market. It is laborintensive, and factories expend great effort to trained and manage local workers. The manufacture of leather products is a strategic sub-sector for the economic and is labor-intensive, and is a good source of employment which constitutes about $5 \%$ of total industrial employment

\section{Marketing and Sales}

Leather can be demanded both local and international, this can have occurred in all value chain of leather processing starting from at abattoirs, Tanning, manufacturing from raw skin and hide, semi process and finished product. Dominantly, Raw materials and semifinished leathers tend to be exported, while finished products are sold on the domestic market. The main exporting customers have changed from leather processing factories to leather products manufacturers; as such, customers look for new buyers and adjust their business practices to meet, avail new customer's demands. 


\subsection{Challenges of leather and leather products}

The Ethiopian leather and leather products' industry is constrained by several bottlenecks related to capacity, information and inputs, as well as the institutional and policy environment. The industry has not been able to penetrate the international market for meat, leather and leather products, even though the country is thought to have a comparative advantage. Although the tanning sector has long been engaged in the export market, its products (mainly in low value-added form) remain uncompetitive in international markets. This also applies to the shoe industry. The leather garment and leather goods industry, on the other hand, has been trapped by a multitude of problems, mainly rooted in the poor performance of the value chain. To date, the industry has made very little or no contribution to exports. (Jan Grumiller and Werner Raza, 2019).

The underperformance of Ethiopian leather and leather products was attributed to:

$\checkmark \quad$ A shortage of sufficient and quality hides and skins;

$\checkmark \quad$ Inadequate managerial capacity across all the functional areas;

$\checkmark \quad$ Limited technology utilization and resource optimization;

$\checkmark \quad$ Limited access to finance;

$\checkmark \quad$ Limited preparedness to meet the minimum export requirements of finished leather;

$\checkmark$ Low factor productivity and low margins from the export of footwear, among others

In general, micro, small and medium enterprises expressed frustration with the government's anticompetitive practices of tax administration, customs and trade regulations, access to land and preferential treatment with regard to licenses, land leases, accessing some resources and opportunities such as public markets, credit, allocation of foreign exchange and contracts. In addition, stringent and punitive measures, such as high tax rates, legal action taken against defaulting units and a lack of dialogue between the state and micro, small and medium-scale enterprises, are promoting suspicion, mistrust, individualistic behavior and informality.

Low and deteriorating supply and quality of raw hides and skins is due to

$>$ Animal husbandry practices; Collection /trade system; Infrastructure (i.e home slaughtering predominates, limited availability of abattoirs and veterinary services etc.

$>$ Limited capacities/capabilities to supply high quality and a large variety of finished leather

$>$ Limited capacities/capabilities of locally - owned manufacturers to fulfil stringent buyer requirements

$>$ Dependency on accessories imports, Limited access to finance and forex; Low wages/high labor turnover, Deteriorating, quality of raw hides and skins supply is a result of parasitic skin diseases as well as the prevalent animal husbandry (flaying, branding, curing) and postmortem management practices (backyard slaughtering and substandard collection, storage and transportation) in the context of a limited availability of infrastructure and services (abattoirs, veterinary services, etc.). The low commercial value of hides and skins, which limits the interest of farmers to improve current practices (Ibid).

The seasonality of supply due to the three festival seasons in January, September and May adds to the challenge of tanneries to source hides and skins for further processing. As a result,

(i) Tanneries are operating at low capacity utilization rates;

(ii) Global buyers to some extent stopped or reduced imports of finished leather from Ethiopia, in particular since global demand for different colors increased in recent years (black tanned leather might cover defects);

(iii) Leather manufacturers have difficulties to locally source quality leather for export markets. In general, according to Jan Grumiller and Werner Raza,2019 the production of leather and leather product of Ethiopia and its markets have the following challenges.

\section{Limited access to finance}

Many locally-owned companies, in particular smaller companies and actors in the upstream segments of the chain (smallholders, collectors, traders, etc.), suffer from limited access to finance due to a lack of collateral and/or high interest rates. Tanneries used to be the main sources of supplier's finance and provided finance to the big raw hides and skins traders, which in turn advanced loans to their respective suppliers. Tanneries also supply finished leather to leather manufacturers on a consignment basis, financing the downstream industry. However, with the introduction of the export tax on semi-processed leather exports, the latter being a very profitable business, tanneries lost their financial strength. In addition, as a consequence of upgrading into finishing, tanneries' working capital requirements grew over threefold for keeping buffer stocks in the form of raw materials, intermediary inputs, goods in process and finished goods in the prolonged production process. The financial sector was not flexible enough to respond to these new business requirements in a timely manner. Thus, the financial problems could have accumulated and contributed to low capacity utilization rates, foregone economies of scale, low productivity growth and lack of price competitiveness.

\section{Dependence on imported inputs}

Another key bottleneck is the dependence on imported inputs (e.g. chemicals, soles, zippers, etc.), which increases costs, lead times, stock and working capital capacities as well as the need for foreign exchange access. The lack of a local accessories sector that supplies quality inputs is particularly challenging for manufacturers; while 
tanneries suffer from the limited local availability of chemicals and other inputs

III. Increasing competition on the local market

Another challenge for Ethiopian leather manufacturers, in particular footwear, is the increasing competition due to increasing production capacities of locally-owned firms and imports. Despite a $35 \%$ tariff on footwear, imports from China, India and Turkey are flooding the Ethiopian market, limiting opportunities for locally-owned companies to diversify to the local non-leather footwear market. Imports of leather footwear has also increased in the last decade, further increasing the pressure on Ethiopian companies. Many company-owners tend to dismiss the threat of Chinese imports of leather footwear due to low quality imports and increasing awareness of consumers

IV. Minor importance of hides and skins for smallholders

The leather and leather products value chain, in contrast, is of relatively minor importance for smallholders due to the low commercial value of hides and skins, which are considered a byproduct, and explains the big difficulty to improve animal husbandry practices.

\section{Limited horizontal cooperation between companies}

Despite the existence of a business association (ELIA), horizontal cooperation among companies in the Ethiopian LLP sector is limited. As such, there is no common sector strategy that could improve market access (e.g. develop a market access strategy and Ethiopia as a brand, share large orders, facilitate learning across firms, etc.). The main problem is that, on the horizontal level, most companies perceive each other as competitors and not as potential partners.

\subsection{Opportunity of Leather and Leather Products}

The shifting global value chain dynamics and China's decreasing global supply of leather products opened a window of opportunity to link to global value chain and increase exports for low-cost countries such as Ethiopia. Even though global trade development has been sluggish, Ethiopia could increase its market share if the sector's competitiveness can be increased. In addition, not only market opportunities in key consumption markets due to duty-free quota - free market access, but also in the regional markets with high growth potential and the relatively large local market.

The key strengths of the Ethiopian Leather and leather products sector include

$>\quad$ One of the world's largest livestock sector; The availability of high quality and internationally renowned sheep leather; Relatively low production costs (wages, electricity); and

$>\quad$ An institutional regime that is committed to support the Ethiopian Leather and leather products sector and improve its performance through industrial policy.

In addition, Ethiopia has market opportunities on the local, regional and global markets due to

$>$ Duty-free and quota-free market access to key consumption markets;

$>$ Relatively large local market;

$>$ Regional market with high growth potential and market access (Common Market for Eastern and Southern Africa, COMESA).

\section{CONCLUSION AND RECOMMENDATIONS}

\subsection{Conclusion}

In order to attain the objectives of the assessment of the main priorities area and opportunities of Banks for financing in leather sector, by analyzing and the discussion of the data, the following conclusions were drawn:

\# Ethiopia's numerous livestock (resource) has advantage on leather sectors play significant roles in generating income from exporting of the raw hides, skins, and leather sectors. Ethiopia has potential because of the availability of such raw material, and high market supply of demand of leather from excess resource. Raw Hide and skin, and leather and finished leather sector has huge potential to achieve foreign exchange for Ethiopia, it is identified as one of the potential sectors that could play a crucial role in achieving long run the foreign currency earning of the country, expanding employment opportunities and attracting foreign direct investment (FDI) due to abundant labor and excess raw material.

* However, gain from the contribution of this sector to the country's economy is not enough as large livestock population in Ethiopia due to lack of production of final output which can earn high export value, lack of financial availability and technology how know, backyard slaughtering systems, and poor marketing systems and lack of market linkage among leather value chains.

* Ethiopia's raw skin and Hides, leather and finished leather products became highly significant and demanded in many international markets.

* The main export destination of Ethiopian leather and leather product are: China, Europe union's countries (Italy, Germany, UK.), Japan, Hong Kong, United States of America, the main source of foreign exchange earner in each year. 
* The leather interlinked in each stage process market channel and export can be performed in all stage value chain (at raw skin and hide, semifinished in tanning and at finished final product at the end of manufacturing) of leather product in which bank can get comparative advantage in investing the leather industry.

\subsection{Recommendations}

Based on the data of assessment and the conclusions drawn above, the following recommendation is made:

* Banks have better to financing and work cooperatively with national and international organizations' exporter of Raw skin and hides and leather and finished leather output to of international market, by developing Strategy, so that Banks can have got higher comparative

Reference advantage from the sector by collecting enough foreign currency gains from such potential sector.

1. World Bank Group,2015.

2. Jan Grumiller and Werner Raza,2019

3. Ethiopian central statistics agency (CSA, 2012)

4. World Trade Organization (WTO,2015)

5. Global Statistics, 2018

6. International trade Corporation (ITC, 2019)

7. Leather Industry Development Institute (LIDI ,2019)

8. United States of America International Aid Development (USAID, 2013).

\section{Appendix: I Importing country of final product of leather product}

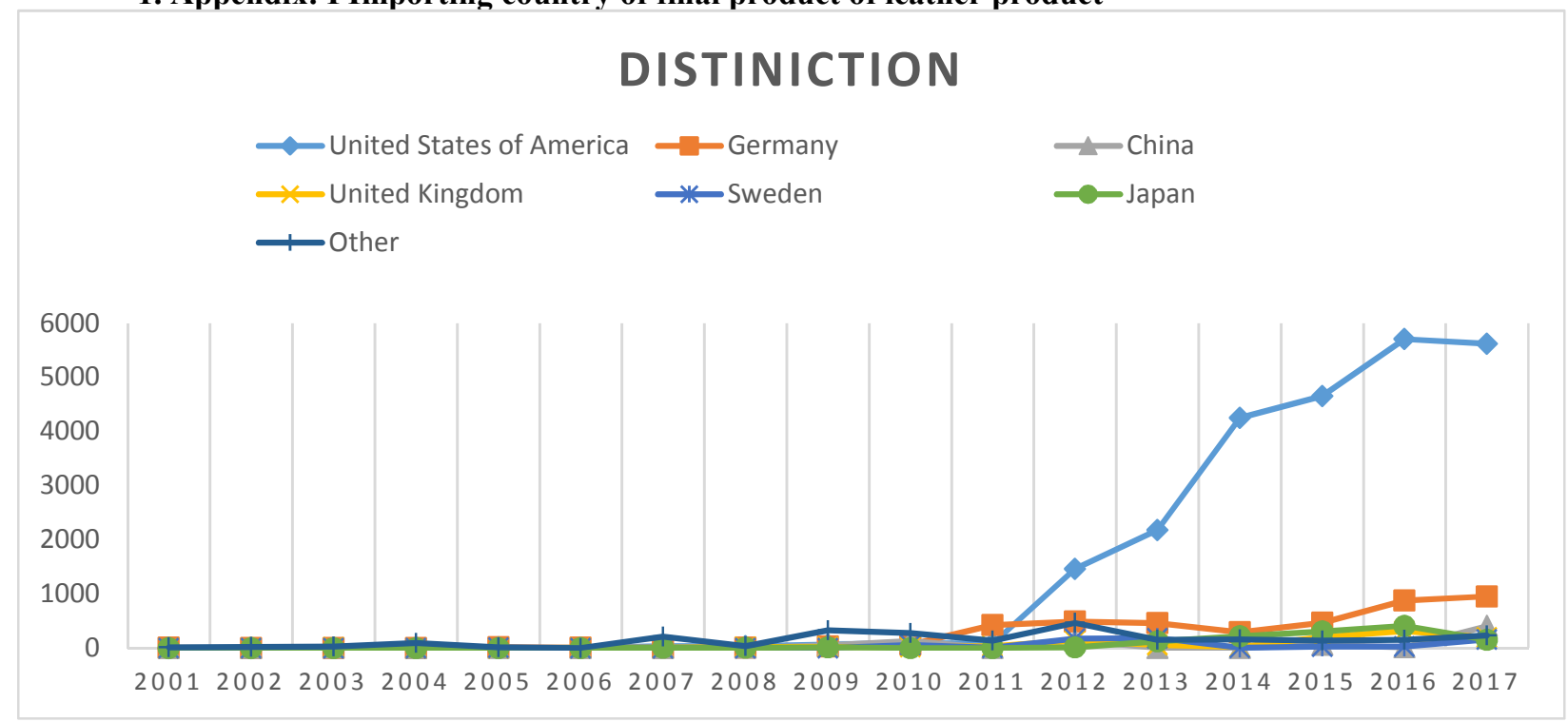




\section{Appendix: I Export Trends of Types of leather product}

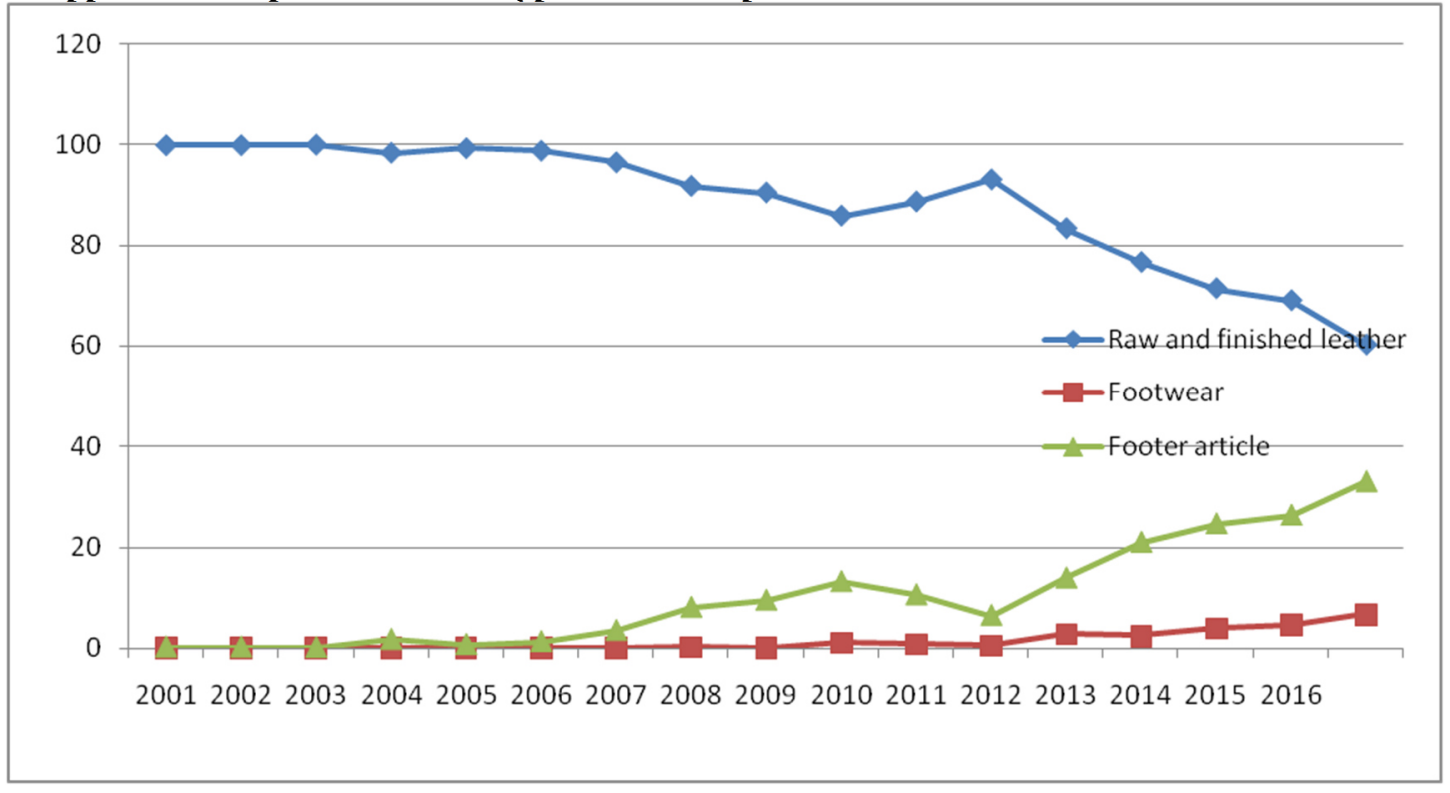

3.Appendex III: Total Ethiopian Export, Share of leather export,

\begin{tabular}{|l|l|l|l|l|l|l|l|}
\hline Year & Total export in & $\begin{array}{l}\text { Growth } \\
\text { USD }\end{array}$ & $\begin{array}{l}\text { Leather and } \\
\text { leather } \\
\text { products in } \\
\text { USD }\end{array}$ & & $\begin{array}{l}\text { Growth } \\
\text { in \% }\end{array}$ & \multicolumn{3}{|l|}{$\begin{array}{l}\text { Share of different categories of leather } \\
\text { sector in \% }\end{array}$} \\
\cline { 5 - 9 } & & & & $\begin{array}{l}\text { Raw and } \\
\text { finished } \\
\text { leather }\end{array}$ & Footwear & $\begin{array}{l}\text { Footer } \\
\text { article }\end{array}$ \\
\hline 2000 & $482,208,308.02$ & - & $47,652,259.65$ & - & 99.8 & 0 & 0.2 \\
\hline 2001 & $453,629,175.77$ & -5.9 & $77,772,681.13$ & 63.2 & 99.8 & 0 & 0.2 \\
\hline 2002 & $473,855,023.22$ & 4.5 & $64,411,924.10$ & -17.2 & 99.9 & 0 & 0.1 \\
\hline 2003 & $581,545,810.57$ & 22.7 & $57,684,043.71$ & -10.4 & 98.3 & 0 & 1.7 \\
\hline 2004 & $615,752,578.36$ & 5.9 & $68,667,465.12$ & 19.0 & 99.2 & 0.1 & 0.7 \\
\hline 2005 & $896,631,487.67$ & 45.6 & $71,956,095.22$ & 4.8 & 98.7 & 0.1 & 1.3 \\
\hline 2006 & $999,387,458.24$ & 11.5 & $83,964,370.64$ & 16.7 & 96.4 & 0 & 3.5 \\
\hline 2007 & $1,183,268,582.46$ & 18.4 & $100,493,469.33$ & 19.7 & 91.7 & 0.2 & 8.1 \\
\hline 2008 & $1,542,860,713.62$ & 30.4 & $101,593,430.69$ & 1.1 & 90.4 & 0.1 & 9.5 \\
\hline 2009 & $1,493,635,742.93$ & -3.2 & $48,751,035.85$ & -52.0 & 85.8 & 1.0 & 13.2 \\
\hline 2010 & $2,147,314,404.94$ & 43.8 & $73,154,831.72$ & 50.0 & 88.6 & 0.8 & 10.6 \\
\hline 2011 & $2,542,304,496.32$ & 18.4 & $130,296,041.83$ & 78.1 & 93.0 & 0.5 & 6.5 \\
\hline 2012 & $2,741,297,675.80$ & 7.8 & $101,421,705.74$ & -22.2 & 83.3 & 2.8 & 13.9 \\
\hline 2013 & $2,591,041,908.59$ & -5.5 & $131,893,086.53$ & 30.0 & 76.6 & 2.4 & 21.0 \\
\hline 2014 & $2,977,916,071.87$ & 14.9 & $125,480,422.74$ & -4.9 & 71.4 & 3.9 & 24.7 \\
\hline 2015 & $2,697,079,937.16$ & -9.4 & $126,616,305.52$ & 0.9 & 69.0 & 4.6 & 26.4 \\
\hline 2016 & $2,615,930,716.16$ & -3.0 & $111,192,963.00$ & -12.2 & 60.2 & 6.7 & 33.1 \\
\hline Average & $\mathbf{1 , 5 9 0 , 3 3 2 , 9 4 7 . 0 0}$ & $\mathbf{1 2 . 3}$ & $\mathbf{8 9 , 5 8 8 , 3 6 0 . 7 0}$ & $\mathbf{1 0 . 3}$ & $\mathbf{8 8 . 4}$ & $\mathbf{1 . 3}$ & $\mathbf{1 0 . 3}$ \\
\hline
\end{tabular}


3. Appendix: IV Definition of Leather product

\begin{tabular}{|c|c|c|c|}
\hline Code & Product Definition & Code & Product Definition \\
\hline '6403 & Footwear & '6406 & $\begin{array}{l}\text { Parts of footwear, incl. uppers whether or not attached } \\
\text { to soles other than outer soles; removable in-soles, } \\
\text { heel cushions and similar articles; gaiters, leggings } \\
\text { and similar articles, and parts thereof (excluding } \\
\text { articles of asbestos) }\end{array}$ \\
\hline '4112 & $\begin{array}{l}\text { Semi Leather tanning or } \\
\text { crusting leather and patent } \\
\text { laminated leather, }\end{array}$ & $' 4104$ & $\begin{array}{l}\text { Tanned or crust hides and skins of bovine "incl. } \\
\text { buffalo" or equine animals, without hair on, whether } \\
\text { or not split (excluding further prepared) }\end{array}$ \\
\hline '4113 & $\begin{array}{l}\text { Leather further prepared after } \\
\text { tanning or crusting "incl. } \\
\text { parchment-dressed leather", } \\
\text { of goats or kids, pigs, reptiles } \\
\text { and other animals, without } \\
\text { wool or hair on, and leather of } \\
\text { hairless animals, whether or } \\
\text { not split (excluding leather of } \\
\text { bovine and equine animals, } \\
\text { sheep and lambs, and chamois } \\
\text { leather, patent leather and } \\
\text { patent laminated leather, and } \\
\text { metallised leather) }\end{array}$ & '4101 & $\begin{array}{l}\text { Raw hides and skins of bovine "incl. buffalo" or } \\
\text { equine animals, fresh, or salted, dried, limed, pickled } \\
\text { or otherwise preserved, whether or not dehaired or } \\
\text { split (excluding tanned, parchment-dressed or further } \\
\text { prepared) }\end{array}$ \\
\hline$' 4105$ & $\begin{array}{l}\text { Tanned or crust skins of sheep } \\
\text { or lambs, without wool on, } \\
\text { whether or not split } \\
\text { (excluding further prepared) }\end{array}$ & '4103 & $\begin{array}{l}\text { Other raw hides and skins, fresh, or salted, dried, } \\
\text { limed, pickled or otherwise preserved, whether or not } \\
\text { dehaired or split (excluding those of bovine animals, } \\
\text { equine animals, sheep and lambs, those with wool on } \\
\text { and those of goats or kids from Yemen, Mongolia or } \\
\text { Tibet and tanned, parchment-dressed or further } \\
\text { prepared) }\end{array}$ \\
\hline '4202 & $\begin{array}{l}\text { Trunks, suitcases, vanity } \\
\text { cases, executive-cases, } \\
\text { briefcases, school satchels, } \\
\text { spectacle cases, binocular } \\
\text { cases, camera cases, musical } \\
\text { instrument cases, gun cases, } \\
\text { holsters and similar } \\
\text { containers; travelling-bags, } \\
\text { insulated food or beverage } \\
\text { bags, toilet bags, rucksacks, } \\
\text { handbags, shopping-bags, } \\
\text { wallets, purses, map-cases, } \\
\text { cigarette-cases, tobacco- } \\
\text { pouches, tool bags, sports } \\
\text { bags, bottle-cases, jewellery } \\
\text { boxes, powder-boxes, cutlery } \\
\text { cases and similar containers, } \\
\text { of leather or of composition } \\
\text { leather, of sheeting of plastics, } \\
\text { of textile materials, of } \\
\text { vulcanised fibre or of } \\
\text { paperboard, or wholly or } \\
\text { mainly covered with such } \\
\text { materials or with paper }\end{array}$ & '4205 & $\begin{array}{l}\text { Articles of leather or composition leather (excluding } \\
\text { saddlery and harness bags; cases and similar } \\
\text { containers; apparel and clothing accessories; whips, } \\
\text { riding-crops and similar of heading 6602; furniture; } \\
\text { lighting appliances; toys; games; sports articles; } \\
\text { buttons and parts thereof; cuff links, bracelets or other } \\
\text { imitation jewellery; made-up articles of netting of } \\
\text { heading 5608; and articles of plaiting materials) }\end{array}$ \\
\hline
\end{tabular}




\begin{tabular}{|c|c|c|c|}
\hline Code & Product Definition & Code & Product Definition \\
\hline 4203 & $\begin{array}{l}\text { Articles of apparel and } \\
\text { clothing accessories, of } \\
\text { leather or composition leather } \\
\text { (excluding footware and } \\
\text { headgear and parts thereof, } \\
\text { and goods of chapter 95, e.g. } \\
\text { shin guards, fencing masks) }\end{array}$ & '6405 & $\begin{array}{l}\text { Footwear with outer soles of rubber or plastics, with } \\
\text { uppers other than rubber, plastics, leather or textile } \\
\text { materials; footwear with outer soles of leather or } \\
\text { composition leather, with uppers other than leather or } \\
\text { textile materials; footwear with outer soles of wood, } \\
\text { cork, twine, paperboard, furskin, woven fabrics, felt, } \\
\text { nonwovens, linoleum, raffia, straw, loofah, etc and } \\
\text { uppers of any type of material, n.e.s. }\end{array}$ \\
\hline '6402 & $\begin{array}{l}\text { Footwear with outer soles and } \\
\text { uppers of rubber or plastics } \\
\text { (excluding waterproof } \\
\text { footwear of heading 6401, } \\
\text { orthopaedic footwear, skating } \\
\text { boots with ice or roller skates } \\
\text { attached, and toy footwear) }\end{array}$ & $' 4114$ & $\begin{array}{l}\text { Chamois leather, incl. combination chamois leather } \\
\text { (excluding glacé-tanned leather subsequently treated } \\
\text { with formaldehyde and leather stuffed with oil only } \\
\text { after tanning); patent leather and patent laminated } \\
\text { leather; metallised leather (excluding lacquered or } \\
\text { metallised reconstituted leather) }\end{array}$ \\
\hline 4106 & $\begin{array}{l}\text { Tanned or crust hides and } \\
\text { skins of goats or kids, pigs, } \\
\text { reptiles and other animals, } \\
\text { without wool on, and leather } \\
\text { of hairless animals, whether } \\
\text { or not split (excluding further } \\
\text { prepared and leather of bovine } \\
\text { and equine animals, sheep and } \\
\text { lambs) }\end{array}$ & $' 4201$ & $\begin{array}{l}\text { Saddlery and harness for any animal, incl. traces, } \\
\text { leads, knee pads, muzzles, saddle cloths, saddlebags, } \\
\text { dog coats and the like, of any material (excluding } \\
\text { harnesses for children and adults, riding whips and } \\
\text { other goods of heading 6602) }\end{array}$ \\
\hline 4107 & $\begin{array}{l}\text { Leather further prepared after } \\
\text { tanning or crusting "incl. } \\
\text { parchment-dressed leather", } \\
\text { of bovine "incl. buffalo" or } \\
\text { equine animals, without hair } \\
\text { on, whether or not split } \\
\text { (excluding chamois leather, } \\
\text { patent leather and patent } \\
\text { laminated leather, and } \\
\text { metallised leather) }\end{array}$ & '6401 & $\begin{array}{l}\text { Waterproof footwear with outer soles and uppers of } \\
\text { rubber or of plastics, the uppers of which are neither } \\
\text { fixed to the sole nor assembled by stitching, riveting, } \\
\text { nailing, screwing, plugging or similar processes } \\
\text { (excluding orthopaedic footwear, toy footwear, } \\
\text { skating boots with ice skates attached, shin-guards } \\
\text { and similar protective sportswear) }\end{array}$ \\
\hline '6404 & $\begin{array}{l}\text { Footwear with outer soles of } \\
\text { rubber, plastics, leather or } \\
\text { composition leather and } \\
\text { uppers of textile materials } \\
\text { (excluding toy footwear) }\end{array}$ & $' 4102$ & Raw skins of sheep or lambs, fresh,other \\
\hline '6406 & $\begin{array}{l}\text { Parts of footwear, incl. uppers } \\
\text { whether or not attached to } \\
\text { soles other than outer soles; } \\
\text { removable in-soles, heel } \\
\text { cushions and similar articles; } \\
\text { gaiters, leggings and similar } \\
\text { articles, and parts thereof } \\
\text { (excluding articles of } \\
\text { asbestos) }\end{array}$ & $' 4110$ & $\begin{array}{l}\text { Parings and other waste of leather, parchment-dressed } \\
\text { leather or composition leather, not suitable for the } \\
\text { manufacture of leather articles; leather dust, powder } \\
\text { and flour }\end{array}$ \\
\hline 4104 & $\begin{array}{l}\text { Tanned or crust hides and } \\
\text { skins of bovine "incl. buffalo" } \\
\text { or equine animals, without } \\
\text { hair on, whether or not split } \\
\text { (excluding further prepared) }\end{array}$ & '4111 & $\begin{array}{l}\text { Composition leather based on leather or leather fibre, } \\
\text { in slabs, sheets or strip, whether or not in rolls }\end{array}$ \\
\hline
\end{tabular}




\begin{tabular}{|c|c|c|c|}
\hline Code & Product Definition & Code & Product Definition \\
\hline 4101 & $\begin{array}{l}\text { Raw hides and skins of bovine } \\
\text { "incl. buffalo" or equine } \\
\text { animals, fresh, or salted, } \\
\text { dried, limed, pickled or } \\
\text { otherwise preserved, whether } \\
\text { or not dehaired or split } \\
\text { (excluding tanned, } \\
\text { parchment-dressed or further } \\
\text { prepared) }\end{array}$ & 4115 & $\begin{array}{l}\text { Composition leather with a basis of leather or leather } \\
\text { fibre, in slabs, sheets or strip, }\end{array}$ \\
\hline 4103 & $\begin{array}{l}\text { Other raw hides and skins, } \\
\text { fresh, or salted, dried, limed, } \\
\text { pickled or otherwise } \\
\text { preserved, whether or not } \\
\text { dehaired or split (excluding } \\
\text { those of bovine animals, } \\
\text { equine animals, sheep and } \\
\text { lambs, those with wool on and } \\
\text { those of goats or kids from } \\
\text { Yemen, Mongolia or Tibet } \\
\text { and tanned, parchment- } \\
\text { dressed or further prepared) }\end{array}$ & $' 4204$ & $\begin{array}{l}\text { Articles for technical use, of leather or composition } \\
\text { leather }\end{array}$ \\
\hline 4205 & $\begin{array}{l}\text { Articles of leather or } \\
\text { composition leather } \\
\text { (excluding saddlery and } \\
\text { harness bags; cases and } \\
\text { similar containers; apparel } \\
\text { and clothing accessories; } \\
\text { whips, riding-crops and } \\
\text { similar of heading 6602; } \\
\text { furniture; lighting appliances; } \\
\text { toys; games; sports articles; } \\
\text { buttons and parts thereof; cuff } \\
\text { links, bracelets or other } \\
\text { imitation jewellery; made-up } \\
\text { articles of netting of heading } \\
\text { 5608; and articles of plaiting } \\
\text { materials) }\end{array}$ & 4206 & Articles of gut, goldbeater's skin, bladders or tendons \\
\hline '6405 & $\begin{array}{l}\text { Footwear with outer soles of } \\
\text { rubber or plastics, with uppers } \\
\text { other than rubber, plastics, } \\
\text { leather or textile materials; } \\
\text { footwear with outer soles of } \\
\text { leather or composition } \\
\text { leather, with uppers other than } \\
\text { leather or textile materials; } \\
\text { footwear with outer soles of } \\
\text { wood, cork, twine, } \\
\text { paperboard, furskin, woven } \\
\text { fabrics, felt, nonwovens, } \\
\text { linoleum, raffia, straw, } \\
\text { loofah, etc and uppers of any } \\
\text { type of material, n.e.s. }\end{array}$ & $' 4201$ & $\begin{array}{l}\text { Saddlery and harness for any animal, incl. traces, } \\
\text { leads, knee pads, muzzles, saddle cloths, saddlebags, } \\
\text { dog coats and the like, of any material (excluding } \\
\text { harnesses for children and adults, riding whips and } \\
\text { other goods of heading 6602) }\end{array}$ \\
\hline
\end{tabular}




\begin{tabular}{|c|c|c|c|}
\hline Code & Product Definition & Code & Product Definition \\
\hline '4114 & $\begin{array}{l}\text { Chamois leather, incl. } \\
\text { combination chamois leather } \\
\text { (excluding glacé-tanned } \\
\text { leather subsequently treated } \\
\text { with formaldehyde and } \\
\text { leather stuffed with oil only } \\
\text { after tanning); patent leather } \\
\text { and patent laminated leather; } \\
\text { metallised leather (excluding } \\
\text { lacquered or metallised } \\
\text { reconstituted leather) }\end{array}$ & '6401 & $\begin{array}{l}\text { Waterproof footwear with outer soles and uppers of } \\
\text { rubber or of plastics, the uppers of which are neither } \\
\text { fixed to the sole nor assembled by stitching, riveting, } \\
\text { nailing, screwing, plugging or similar processes } \\
\text { (excluding orthopaedic footwear, toy footwear, } \\
\text { skating boots with ice skates attached, shin-guards } \\
\text { and similar protective sportswear) }\end{array}$ \\
\hline 4111 & $\begin{array}{l}\text { Composition leather based on } \\
\text { leather or leather fibre, in } \\
\text { slabs, sheets or strip, whether } \\
\text { or not in rolls }\end{array}$ & $' 4102$ & Raw skins of sheep or lambs, fresh, other \\
\hline 4115 & $\begin{array}{l}\text { Composition leather with a } \\
\text { basis of leather or leather } \\
\text { fibre, in slabs, sheets or strip, }\end{array}$ & $' 4110$ & $\begin{array}{l}\text { Parings and other waste of leather, parchment-dressed } \\
\text { leather or composition leather, not suitable for the } \\
\text { manufacture of leather articles; leather dust, powder } \\
\text { and flour }\end{array}$ \\
\hline 4204 & $\begin{array}{l}\text { Articles for technical use, of } \\
\text { leather or composition leather }\end{array}$ & $' 4206$ & Articles of gut, goldbeater's skin, bladders or tendons \\
\hline
\end{tabular}

